\title{
Immunoregulatory treatment for minimal change nephrotic syndrome
}

\author{
K P MEHTA, U ALI, M KUTTY, AND U KOLHATKAR
}

Nephrology Division and Research Laboratory, Bai Jerbai Wadia Hospital for Children, Parel, Bombay, India

SUMmARY Immunological studies were performed in 18 children with minimal change nephrotic syndrome proved by biopsy examination during relapse and in 15 age matched controls. All 18 children showed dysfunction of cell mediated immunity as evidenced by low absolute lymphocyte count, low blastogenesis index in response to phytohaemagglutinin stimulation, and reduced skin sensitivity to dinitrochlorobenzene when compared with controls. All 18 patients had low serum IgG concentrations, while the IgA, IgM, and $C_{3}$ concentrations in the serum were within normal limits.

Based on the evidence of depressed cell mediated immunity, 14 patients with nephrotic syndrome were treated with an immunoregulatory drug $l$-tetramisole (levamisole) for a period of 20-24 weeks. Six patients went into complete remission within 4-20 weeks of treatment, a further six patients went into partial remission, while two did not respond.

On follow up (six to 24 months after stopping levamisole), of the six patients who achieved complete remission, four continued to maintain the state and two relapsed after roughly six months. Of the six patients who achieved partial remission, two went into complete remission, two continued to be in partial remission, and two relapsed.

A variety of immunological alterations have been described in minimal change nephrotic syndrome. ${ }^{1-3}$ Conventional treatment with steroids and immunosuppressants, although inducing a remission of the nephrotic state, increases the risk of severe life threatening infections in these children by further depressing the cell mediated immunity.

This study was undertaken to evaluate the immunological state of children with minimal change nephrotic syndrome in relapse who were not being given any immunosuppressive treatment and to assess the role of levamisole, an immunoregulatory drug, in the management of this disease in those who showed evidence of dysfunction in cell mediated immunity.

\section{Patients and methods}

Eighteen patients with nephrotic syndrome and 15 controls, all aged between 1 and 12 years, were studied.

All 18 patients had anasarca with proteinuria $\geqslant 40 \mathrm{mg} / \mathrm{m}^{2} / 24$ hours, hypoalbuminaemia $\leqslant 2.5 \mathrm{~g} / \mathrm{dl}$ and hypercholesterolaemia $\geqslant 200 \mathrm{mg} / \mathrm{dl}$. Histology of the renal biopsy specimen obtained percutaneously showed a minimal lesion in all 18 cases on light microscopy; the immunofluorescence was negative in all except one, which had faint deposits of IgM in mesangium.

The patients were further classified according to whether they had (a) single attacks, (b) infrequent relapses (<three a year), (c) frequent relapses ( $>$ two in six months or $>$ three a year). None of them were receiving any immunosuppressants at the time of the study. Only two had earlier received cyclophosphamide, and that was more than two years before the present study. Immunological studies were undertaken on all these patients.

Tests for cell mediated immunity. These were (1) absolute $\mathrm{T}$ lymphocyte count by sheep red blood cell rosette formation; (2) blastogenesis by phytohaemagglutinin stimulation; and (3) skin testing for delayed hypersensitivity to neoantigen dinitrochlorobenzene.

Tests for humoral immunity. These were (1) absolute B lymphocyte count by rosette formation; and 
(2) estimation of immunoglobulins IgG, IgM, and $\operatorname{IgA}$ in serum by electroimmunoassay (Rocket technique).

Complement system. Estimation of $\mathrm{C}_{3}$ component in serum was by single radial immunodiffusion.

Treatment with levamisole. Fourteen patients were given levamisole $(2.5 \mathrm{mg} / \mathrm{kg}$ body weight $)$ as a single dose at bed time either daily or on alternate days for a period of 20-24 weeks. During this period they were observed clinically with special reference to weight, blood pressure, oedema, and the number and severity of infections. Laboratory monitoring was performed weekly by blood count and complete urinalysis and monthly for blood urea, serum creatinine, and 24 hours urinary albumin concentra- tions. Serum proteins and cholesterol were assessed at the end of treatment. Immunological studies were repeated when possible at the end of treatment. Response was termed as complete remission when the urine was free of albumin in three consecutive samples. Partial remission was when there was a reduction in proteinuria to + or ++ and the patient was free of oedema. No response was when there was no reduction in proteinuria. The patients were followed up for six months to two and a half years to assess their nephrotic state.

\section{Results}

There were 18 patients in relapse aged 1-12 years and 15 age matched controls. Tables 1 and 2 show the results of their immunological studies, respec-

Table 1 Results of immunological study in 18 patients with minimal change nephrotic syndrome

\begin{tabular}{|c|c|c|c|c|c|c|c|c|c|c|}
\hline $\begin{array}{l}\text { Case } \\
\text { no }\end{array}$ & $\begin{array}{l}\text { Haemo- } \\
\text { globin } \\
(\mathrm{g} / \mathrm{l})\end{array}$ & $\begin{array}{l}\text { Serum } \\
\text { albumin } \\
(\mathrm{g} / \mathrm{dl})\end{array}$ & $\begin{array}{l}\text { Skin reactivity } \\
\text { to dinitro- } \\
\text { chlorobenzene } \\
\text { (grade) }\end{array}$ & $\begin{array}{l}\text { Absolute } \\
\text { mononuclear } \\
\text { cell count } \\
\text { (per } \mathrm{mm}^{3} \text { ) }\end{array}$ & $\begin{array}{l}T \text { cell } \\
\text { count } \\
\left.\text { (per } \mathrm{mm}^{3}\right)\end{array}$ & $\begin{array}{l}\text { B cell } \\
\text { count } \\
\text { (per } \mathrm{mm}^{3} \text { ) }\end{array}$ & $\begin{array}{l}\text { Phyto- } \\
\text { haemagglutinin } \\
\text { index at } \\
72 \text { hours }\end{array}$ & $\begin{array}{l}\operatorname{IgG} \\
(m g / d l)\end{array}$ & $\begin{array}{l}\operatorname{Ig} A \\
(m g / d l)\end{array}$ & $\begin{array}{l}\lg M \\
(m g / d l)\end{array}$ \\
\hline 1 & 114 & $2 \cdot()$ & 2 & 5587 & 1898 & 509 & $3 \cdot 8$ & 50() & 84 & 176 \\
\hline 2 & 128 & 1.4 & 2 & 3696 & 1182 & 81.3 & $2 \cdot 1$ & 400 & 124 & 190 \\
\hline 3 & 136 & $1 \cdot 0$ & 3 & 14411 & 648 & 403 & $1 \cdot 8$ & 640 & 94 & 129 \\
\hline 4 & 97 & 0.8 & 0 & 3744 & 1835 & 973 & $1 \cdot 2$ & 520 & 80 & 146 \\
\hline 6 & 118 & $2 \cdot 1$ & 2 & 4575 & 100107 & 685 & $3 \cdot 6$ & 528 & 74 & 260 \\
\hline 7 & 114 & $2 \cdot 2$ & 0 & 1760 & 387 & 176 & 3.4 & 400 & 74 & 140 \\
\hline 8 & 118 & 0.6 & 2 & 4312 & 1207 & 10.35 & $2 \cdot 8$ & 580 & 68 & 120 \\
\hline 9 & 100 & $1 \cdot 8$ & 2 & 34.32 & 1304 & 309 & $6 \cdot 2$ & 840 & 114 & 138 \\
\hline 10) & 132 & 0.9 & 1 & 5928 & 512 & 1363 & $3 \cdot 11$ & 480 & 84 & 180 \\
\hline 11 & 112 & $0 \cdot 6$ & 0 & 23.31 & 6.52 & 3013 & $2 \cdot 6$ & 460 & $1(x)$ & 136 \\
\hline 12 & 125 & $2 \cdot 5$ & 0 & 34.32 & 1510 & +12 & $1 \cdot 2$ & 380 & 64 & 120 \\
\hline 13 & 104 & 1.9 & 2 & 3808 & 1312 & 6019 & $3 \cdot 2$ & 840 & 110 & 143 \\
\hline 14 & 110 & 1.5 & 2 & 24.30 & 1966 & 4.37 & 3.6 & 480 & 48 & 120 \\
\hline 16 & 120 & 1.2 & 0 & 3393 & 124.3 & 238 & 4.9 & 720 & 96 & 154 \\
\hline 17 & 114 & $1 \cdot 5$ & 1 & $4(1) 12$ & 1387 & 422 & 3.6 & 840 & 84 & 126 \\
\hline 18 & 108 & $1 \cdot 8$ & 0 & 6574 & 1942 & 1052 & $3 \cdot 4$ & 800 & 102 & 134 \\
\hline
\end{tabular}

Table 2 Results of immunological study in the 15 controls

\begin{tabular}{|c|c|c|c|c|c|c|c|c|c|c|}
\hline $\begin{array}{l}\text { Case } \\
\text { no }\end{array}$ & $\begin{array}{l}\text { Haemo- } \\
\text { globin } \\
(\mathrm{g} / \mathrm{l})\end{array}$ & $\begin{array}{l}\text { Serum } \\
\text { albumin } \\
\text { (g/dl) }\end{array}$ & $\begin{array}{l}\text { Skin reactivity } \\
\text { to dinitro- } \\
\text { chlorobenzene } \\
\text { (grade) }\end{array}$ & $\begin{array}{l}\text { Absolute' } \\
\text { mononuclear } \\
\text { cell count } \\
\text { (per mm') }\end{array}$ & $\begin{array}{l}T \text { cell } \\
\text { count } \\
\left.\text { (per } \mathrm{mm}^{3}\right)\end{array}$ & $\begin{array}{l}B \text { cell } \\
\text { count } \\
\left.\text { (per } \mathrm{mm}^{i}\right)\end{array}$ & $\begin{array}{l}\text { Phyto. } \\
\text { hacmagglutinin } \\
\text { index at } \\
72 \text { hours }\end{array}$ & $\begin{array}{l}\lg (; \\
(m g / d l)\end{array}$ & $\begin{array}{l}\lg A \\
(m g / d l)\end{array}$ & $\begin{array}{l}\lg M \\
(m g / d l)\end{array}$ \\
\hline 1 & 142 & 3.9 & 3 & $48(x)$ & 3168 & 1056 & 5.8 & 1100 & $|(1)|$ & 143 \\
\hline 2 & 135 & $3 \cdot 2$ & 2 & $62(x)$ & 4216 & 1426 & 6.6 & 830 & 94 & 186 \\
\hline 3 & 110 & 4.0 & 4 & 2920 & 1119 & 525 & $7 \cdot 4$ & 1.349 & 97 & 96 \\
\hline 4 & 132 & 3.8 & 3 & $\sin (1)$ & 5120 & 1120 & $4 \cdot 4$ & 17601 & 101 & 89 \\
\hline 6 & 112 & 3.5 & Negative & $120(0)$ & 7440 & 2320 & 6.4 & 620 & 97 & 128 \\
\hline 7 & 116 & 3.6 & 3 & $38(k)$ & 2242 & 646 & 4.5 & 622 & 180 & 201 \\
\hline 8 & 113 & $4 \cdot 1$ & 4 & $48(x)$ & 3168 & 672 & 3.9 & 934 & 190 & 190 \\
\hline 9 & 118 & $3 \cdot 7$ & 3 & $32(k)$ & 1888 & 480 & 6.9 & 1760 & 120 & 136 \\
\hline 10 & 111 & 3.4 & 4 & $42(k)$ & 2394 & 672 & $3 \cdot 8$ & 1100 & 120 & 97 \\
\hline 11 & 133 & 3.9 & 3 & $4(x)$ & 2320 & 720 & $6 \cdot x$ & 688 & 160 & 81 \\
\hline 12 & 128 & $3 \cdot 6$ & 4 & $460(1)$ & 2714 & 644 & 3.9 & 948 & 1.38 & 201 \\
\hline 13 & 122 & 3.7 & 4 & $38(0)$ & 2808 & 608 & 9.4 & $11(x)$ & 180 & 96 \\
\hline 14 & 147 & 3.9 & 3 & $24(1)$ & 1512 & 4.32 & $4 \cdot 8$ & 800 & 101 & 138 \\
\hline
\end{tabular}


tively. The statistical analysis of these results are as follows.

The absolute $\mathrm{T}$ lymphocyte count in patients with nephrotic syndrome had a mean (SD) value of 1387 (527). The mean (SD) value for the control group was $3265(1808)(\mathrm{p}<0.001)$ (Figure 1). The blastogenesis index to phytohaemagglutinin stimulation at 72 hours was $2.87(1 \cdot 17$, SEM 0.284$)$ in the patients while the mean (SD) value for the control group was $6.2(2.01$, SEM 0.539) $(p<0.001)$ (Figure 2). The skin reactivity to dinitrochlorobenzene was grade 2 or less in 16 patients, while in the control group 13 had a response of grade 3 or 4 . The mean (SD) value for the absolute $\mathrm{B}$ lymphocytes in nephrotics was 661 (391). In the control group it was 910 (512). The difference was not significant. The serum IgG concentrations in the nephrotic group was $576 \mathrm{mg} \%$ (SD 164, SEM 39) and in the controls was 1072 $\mathrm{mg} \%$ (SD 348, SEM 93) $(\mathrm{p}<0 \cdot 001)$.

The mean (SD, SEM) value for IgA concentrations in the patients with nephrotic syndrome was 87 $(18,4)$. In the controls it was $128(32,8)$. The difference was not significant. The IgM concentrations in the patients with nephrotic syndrome were
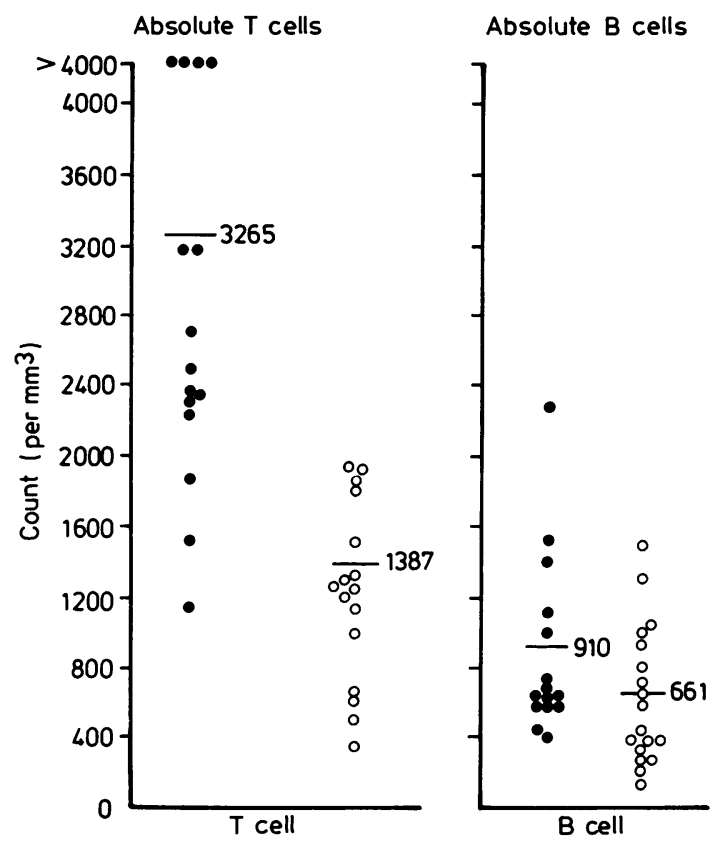

Fig. 1 Absolute $T$ and $B$ cell lymphocyte counts in the group with minimal change nephrotic syndrome $(n=18)$ and the control group $(n=15)$.

Patients with the syndrome are shown by $\dot{o}$, controls by $\bullet(p<0) \cdot(0) 1$ for absolute $T$ cell count: $p$ not significant for absolute $B$ cell count). Values shown are the means.

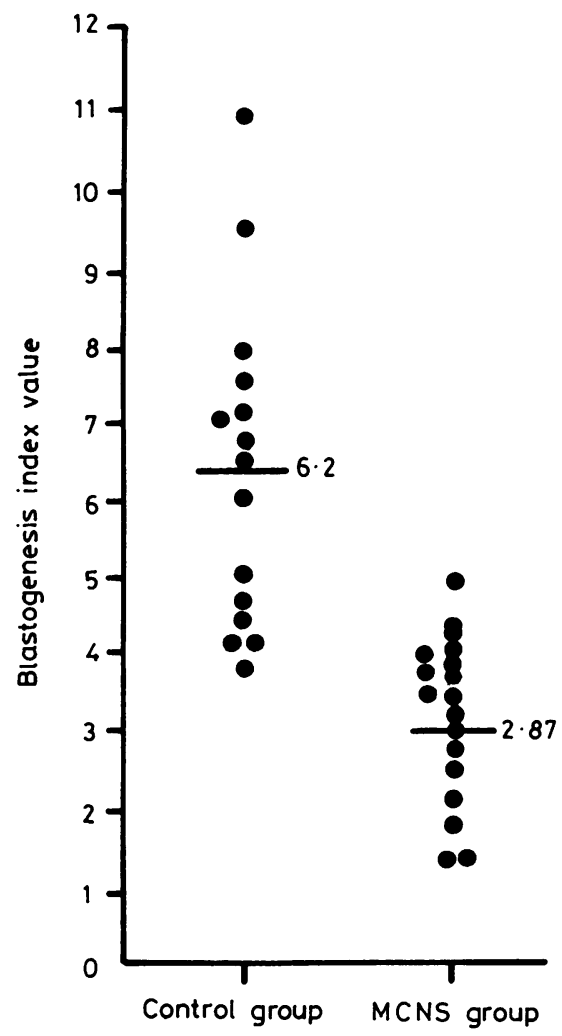

Fig. 2 Blastogenesis index to phytohaemagglutinin stimulation at 72 hours in the group with minimal change nephrotic syndrome $(M C N S)(n=18)$ and the control group $(n=15)$.

$\mathrm{p}<0 \cdot(0) 1$. Value shown is the mean.

150 (SD 33, SEM 8). In the controls it was 140 (SD 41, SEM 11) (Figure 3). The serum complement concentrations in both the groups were within normal limits.

Results of treatment with levamisole. Fourteen patients with nephrotic syndrome were treated with levamisole. Their ages ranged from 1 to 12 years. Two were aged under 2 , six between $2-5$, and six over 5. There were eight boys and six girls. Six patients were seen in the first attack and had never received steroids, while out of the remaining eight cases responsive to steroids five infrequently relapsed and three frequently relapsed. One of those who frequently relapsed was also steroid dependent.

Of these 14 patients, six had complete remission, six had partial remission, and two did not respond to levamisole. The time taken to achieve remission varied from between four and 20 weeks of treat- 

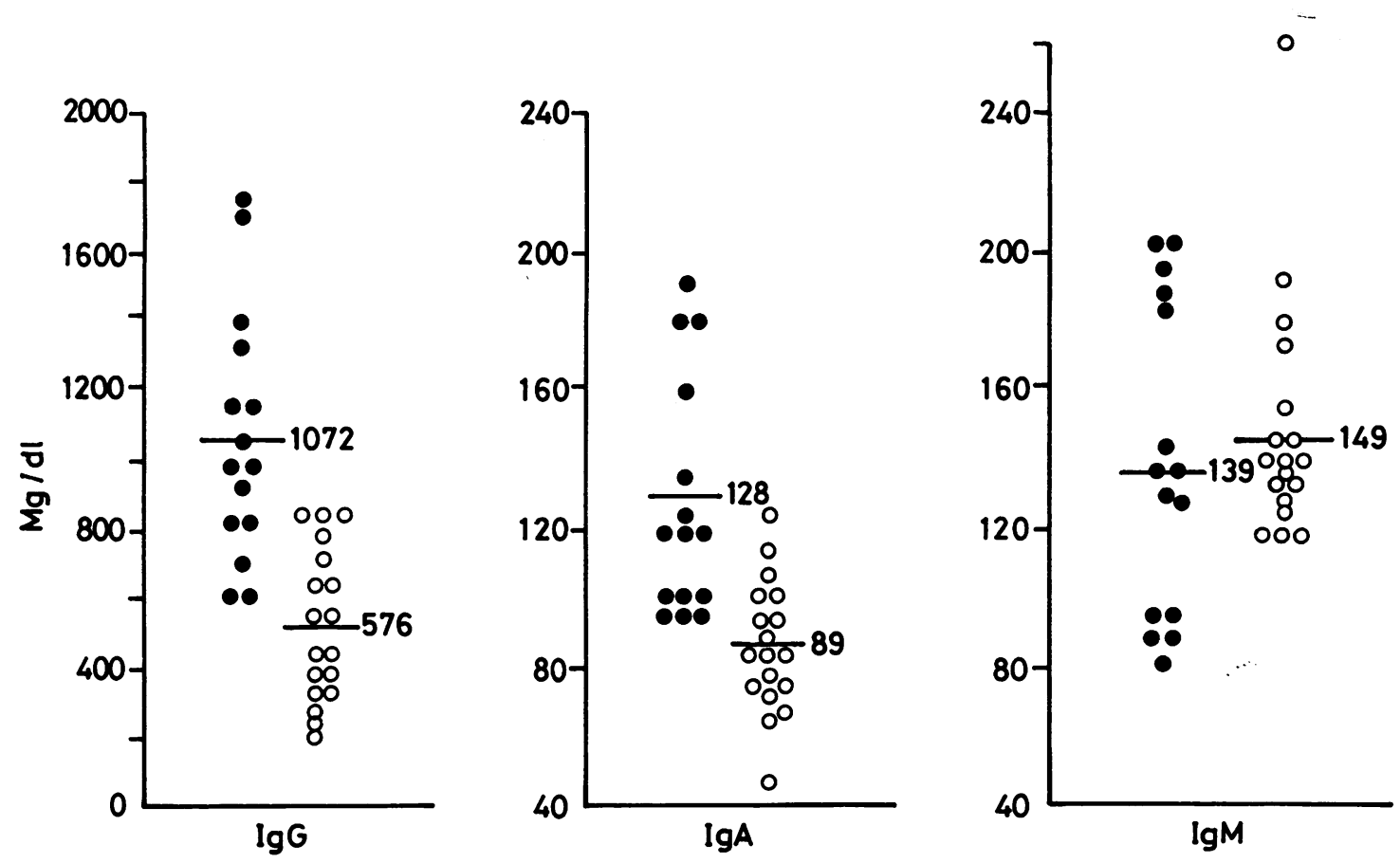

Fig. 3 Serum $\operatorname{Ig} A, \operatorname{IgG}$, and IgM concentrations in the group with minimal change nephrotic syndrome ( $n=18)$ and the control group $(n=15)$.

Patients with the syndrome are shown by $\circ$, controls by $\bullet$. Values shown are the means.

ment, occurring slightly earlier (four to 12 weeks) in those who were on daily treatment. All the six patients aged over 5 showed a good response to treatment with levamisole; three went into complete remission and three into partial remission. Two patients who did not respond were aged under 5 , one seen in first attack and the other who frequently relapsed. Of six patients seen in the first attack, four went into complete and one into partial remission. Of the five patients who infrequently relapsed, one went into complete remission and four into partial remission. Of these four in partial remission, two went immediately into complete remission after stopping treatment with levamisole. Of the three who frequently relapsed, one went into complete remission, one into partial remission, and one failed to respond. None of the 14 patients suffered from any severe infection during the six months. There was a reduced prevalence of infections most noticeable in six patients who had more than five episodes of severe infections in the previous year.

Side effects. Minor side effects were seen in those receiving daily treatment. These included vomiting in three cases, rash in one, and transient haematuria in two.

On follow up of 12 patients who showed an initial response to treatment with levamisole in the form of complete or partial remission, 6 months after stopping treatment, seven were in complete remission (five of six from the complete remission group, two of six from the partial remission group). Two were in partial remission, and three relapsed. Follow up of one to two years showed 7 of 12 in complete remission and 1 of 12 in partial remission.

Immunological studies after treatment with levamisole. $T$ cell, B cell enumeration and blastogenesis index was repeated in two patients after remission induced by levamisole. In both these patients the blastogenesis index had increased. Immunoglobulins were repeated in seven patients. Six (five in complete and one in partial remission) showed increase in IgG concentration to more than twice the pretreatment values. In one patient in partial remission the IgG concentration was still low. 


\section{Discussion}

Infections account for more than half the deaths due to minimal change nephrotic syndrome. ${ }^{4}$ They are also responsible for the considerable morbidity seen in this disease. This increased vulnerability to infection can be accounted for by the depression in the immunological system as seen by the low cell count, depressed blastogenesis, poor skin reactivity to dinitrochlorobenzene, and low serum IgG concentrations.

Decreased response of lymphocytes to mitogens has been described in active nephrotic syndrome by several authors, ${ }^{5-7}$ as has the poor skin reactivity to dinitrochlorobenzene. ${ }^{58}$ Most authors, however, have reported the $T$ cell to be numerically normal, 57 except in one other study by Tanphaichitr et al where the T cell counts were found to be low. ${ }^{9}$ Low $T$ cell counts were uniformly present in all our patients, only two of whom had received previous treatment with Endoxan, which is known to have a prolonged depressive effect on T cells. ${ }^{10}$ Low serum IgG concentrations in relapse has been well documented and cannot be explained on urinary losses alone. ${ }^{11} 12$

It has not been established whether the depression in cell mediated immunity is a primary event or secondary to the hypoalbuminaemia, hyperlipidaemia, or zinc deficiency that coexists in these patients, as all these factors are known to depress cell mediated immunity. ${ }^{13-15}$ It has been postulated that an abnormal immunogenic response to some unknown stimuli may be a primary event in patients with nephrotic syndrome, leading to suppression of $\mathrm{T}$ cell functions. This may lead to depressed cell mediated immunity as well as impairment of $\mathrm{T}$ cell dependent $\mathrm{B}$ cell activation accounting for the low concentrations of $\mathrm{IgG}$ in these patients. This same deviated immune response may be responsible for the production of an abnormal lymphokine with properties of increasing vascular permeability. ${ }^{2}$ Such vascular permeability factors have been identified in the sera of patients with active nephrotic syndrome. ${ }^{3}$

Whether a cause or an effect, the immunological dysfunctions increase the risk of serious infections in these patients. The role of immunoregulatory drugs as opposed to immunosuppressive drugs in the management of these immunocompromised patients needs to be explored. Levamisole, used as an antihelminthic, has immunoregulatory properties. It is a non-specific stimulator of lymphocytes and has been found to increase both lymphocyte number and function. This action is particularly noticeable in immune depressed patients. It does not stimulate normal lymphocytes. ${ }^{16}$ It has been successfully used in other immunologically mediated diseases such as rheumatoid arthritis, chronic active hepatitis, and recurrent skin infections. ${ }^{16-18}$ Its successful use in minimal change nephrotic syndrome has been documented in a small number of children. ${ }^{9}$

We found that treatment with levamisole definitely reduced the number and severity of infections that in our experience often accompany or precede a relapse. This beneficial effect is probably due to its stimulant effect on cell mediated immunity. It has been used by some workers to treat certain varieties of recurrent and chronic infections with beneficial results. ${ }^{1617}$ Hence even in those nephrotics who have severe infections levamisole can be administered safely and probably to the advantage of the patient.

As opposed to this, steroids that act by depressing the $T$ cell function increase the incidence and severity of infections, which may even be the cause of death in some instances. ${ }^{4}$ In those patients presenting with infections treatment with steroids has to be postponed till the infection is well under control, thus delaying the beginning of definitive treatment. The effect of levamisole on the proteinuria, however, is slower and less dramatic compared with that of steroids.

In our study complete remission was achieved in six of 14 cases within 4-20 weeks of treatment. A total of 12 of 14 cases showed a definite reduction, however, in the proteinuria with improvement in the nephrotic state. Two of three patients who frequently relapsed benefited by this treatment. One went into complete remission, which was maintained for six months after stopping the drug; this child was steroid dependent, and this was the longest period free of disease that this child has had. The second patient who frequently relapsed remained free of both oedema and infection during the six months of treatment.

Several toxic effects, including agranulocytosis, have been described with the use of levamisole, especially in those receiving high daily doses. ${ }^{16} 1920$ In the schedule used by us there was no serious toxicity. Side effects are fairly common even with the recommended doses of steroids, while the dangerous side effects of prolonged treatment with steroids are well known.

Thus the role of levamisole in the management of minimal change nephrotic syndrome seems to be promising. The restoration of normal lymphocyte function by levamisole possibly helps to eliminate gradually the pathophysiological events leading to a nephrotic state. Further studies on the optimum dosage, regularity of administration, and duration of treatment require further investigation. Newer drugs with more specific actions on lymphocyte 
subpopulations may have a better role in the management of nephrotic syndrome.

We are thankful to the Dean, Bai Jerbai Wadia Hospital for Children, for giving us permission to publish this paper.

\section{References}

' Hoyer JR. Idiopathic nephrotic syndrome with minimal glomerular changes. In: Brenner BM, Stein JH eds. Contemporary issues in nephrology; nephrotic syndrome. Edinburgh: Churchill Livingstone, 1982:145-74.

2 Schlesinger L, Rodriguez E, Fodor $\mathrm{P}$. T cell functions in nephrotic syndrome. In: Brodehl J. Ehrich JHH, eds. Paediatric nephrology. Berlin: Spriger-Verlag, 1984:259-63.

${ }^{3}$ Melvin T, Sibley R, Michael AF. Nephrotic syndrome. In: Tune BM, Mendoza SA, eds. Contemporary issues in nephrology: pediatric nephrology. Edinburgh: Churchill Livingstone, 1984:191-230.

+ Barnett HL, Schoeneman M, Bernstein J, Edelmann CM. Minimal change nephrotic syndrome. In: Edelmann CM, ed. Pediatric kidney disease. Boston: Little Brown and Co, 1978:695-711.

s Fodor P. Saitua MT. Rodriguez E, Gonzales B, Schlesinger LT. Cell dysfunction in minimal change nephrotic syndrome in children. Am J Dis Child 1982:136:713-7.

- Tomizawa S, Suzuki S, Oguri M, Kuroume T. Studies of T lymphocyte function and inhibitory factors in minimal change nephrotic syndrome. Nephron 1979;24:179-85.

${ }^{7}$ Sasdelli M, Rovinetti O. Cagnoli L. Beltrandi E, Barboni F, Zucchelli $P$. Lymphocyte subpopulations in minimal-change nephropathy. Nephron 1980;25:72-6.

${ }^{8}$ Matsumoto K, Osalabe K. Harada M. Matano M. Impaired cell mediated immunity in lipoid nephrosis. Nephron 1981:29:190-4.

${ }^{9}$ Tanphaichitr P. Tanphaichitr D. Sureeratanan J, Chatasingh S.
Treatment of nephrotic syndrome with Levamisole. J Pediatr 1980;96:490)-3.

10 Chapman S, Taube D, Brown Z. Williams DG. Impaired lymphocyte transformation in minimal change nephropathy in remission. Clin Nephrol 1981:15:34-8.

"Sobel AJ, Intrator L. Lagrue G. Serum immunoglobulins in idiopathic minimal change nephrotic syndrome (letter). $N$ Engl $J$ Med 1976:294:50.

12 Meadow SR, Sarsficld JK, Scott DG, Rajah SM. Steroid responsive nephrotic syndrome and allergy. Immunological studies. Arch Dis Child 1981;56:517-24.

13 Chisari FV. Immunoregulatory properties of human plasma in very low density lipoproteins. J Immunol 1977:119:2129-36.

14 Menchaea JA, Lekkowitz S. Hyperlipoproteinaemia cellular immunity and nephrotic syndrome. Lancet 1980;i:1084-5.

15 Reimold EW. Changes in zinc metabolism during the course of the nephrotic syndrome. Am J Dis Child 1980:134:46-50.

16 Asquith P. Clinical use of levamisole-a critical review. In: Thomson RA, ed. Recent advances in clinical immunology. Vol 2. Edinburgh: Churchill Livingstone, 1980:341-60.

17 Businio L. Laurenti F, Rossi P. Galti E, Avuti F. Child with atopy, increase of $\operatorname{IgE}$ and recurrent infections treated with levamisole. Arch Dis Child 1981:561:60-4.

is Thomas HL, Chadwick KG. Jain S. Sherlock S. Levamisole therapy for HBsAg positive chronic liver discase. Gastroenterology 1977;73:52-3.

${ }^{19}$ Levamisole: a cautionary note. Lancet 1979;ii:291-2.

20) Prieur AM. Buriot D. Letuvi JM. Possible toxicity of levamisole in children with rhcumatoid arthritis. J Pediatr 1978:93:3(2-4.

Correspondence to Dr K P Mehta, The Nephrology Division, Bai Jerbai Wadia Hospital for Children, Institute of Child Health and Research Centre, Parel, Bombay 400 012, India.

Received 30 August 1985 